horses, and the crew consisted of two or three people. The springs made it possible to move quickly through a dirty road and virgin, soil.

Used in national liberation competitions in Ukraine in 1917-1921 for close combat. A small, Phacton - a light four-wheder made in the city of Pereiaslav by the master Nikifor Gusakov in the early 20 -th century.

Sharaban - an open four-wheeled crew with transverse benches for easy and fast ride.

The attention is paid to things of road life, thanks to which visitors create a picture of living reality.

The exposition is complemented by the original paintings by Yury Grigorovich Legenky « The Way is a Fate of the Ukrainian People», which are scillfully executed on the walls and include fragments of songs.

The Museum of the Folk Land Transport of the Middle Dnieper is collecting, preserving, studying, exhibiting and promoting the creation of human hands that are connected with the history and practical development of technology and machinery. Therefore, visitors have the opportunity to get acquainted with interesting artifacts that will help them deepen their knowledge of the traditional Ukrainian culture and see vehicles that are no longer used in modern life in the XXI century.

\title{
COLLECTION OF MONUMENTS OF FOLK WOODEN ARCHITECTURE OF THE MUSEUM OF FOLK ARCHITECTURE AND WAY OF LIFE OF MIDDLE NADDNIPRIANSCHYNA OF THE NATIONAL HISTORICAL AND ETNOGRAPHIC RESERVE «PEREIASLAV»)
}

\section{Mykola Shkira ${ }^{1}$}

DOI: https://doi.org/10.30525/978-9934-588-11-2_37

Ukraine is extremely rich in the cultural and spiritual treasures that the people have treasured gathered over a thousand years of history. However, not all of them managed to survive, some of them came to us only in legends, photographs, or were simply destroyed by time. Some of them were fortunate enough to be preserved to this day.

One of such important elements of Ukrainian ethnicity is the original museum complex, which reproduces the true reality - the Research Branch of the Museum of Folk Architecture and Life of the Middle Dnieper region of National Historical and Ethnographic Reserve»Pereiaslav»,which construction started in 1964.

It is a significant research and cultural and educational institution covering extremely wide time frames: the development of the material and spiritual culture of

\footnotetext{
${ }^{1}$ National Historical and Ethnographic Reserve «Pereiaslav», Ukraine
} 
the ethnic groups that inhabited the territory of Ukraine from the late Paleolithic period to the middle of the twentieth century.

Investigations of individual issues of construction of the first open air museum in Ukraine, were covered in the works of M.I. Sikorsky, E.F. Ishchenko, M.I. Jam, G.I. Koziy, D.T. Shvydkyi, G.M. Buzyan, M.G. Makhinchuk, O.V. Kolibenko, Yu.V. Avramenko, T.V. Grudevich, N.G. Tkachenko, V.M. Tkachenko, O.M. Zham, Yu.S. Figurny, M.V. Shkira and others. In the collective monograph dedicated to the 90th anniversary of M.I. Sikorsky: «Mikhailo Ivanovich Sikorsky: Creator of History and Keeper of Time», the history of the creation of the Pereyaslav National Historical and Ethnographic Reserve, search for individual objects of material and spiritual culture, archaeological sites, etc is covered [1].

Pereiaslav skansen was created with taking into account the experience of the best ethnographic museums in the world, as an effective element of preservation and study of Ukrainian ethno-cultural traditions in the conditions of historical challenges of the twentieth century. One of the main founders of the Open Air Museum was Mikhailo Sikorsky (1923-2011).

In the area of 24.2 hectares, 108 monuments of folk wood architecture of the 18th early 20th centuries are exhibited, two sacral monuments of national importance, more than 20 objects have been reconstructed: archeological, residential, commercial and industrial. Two man-made ponds were created and the arboretum was planted.

The exposition of the museum of the Ukrainian village includes twenty yards and residential complexes, which tell about the life of the peasant family of the late 19thearly 20 th centuries.

A special form of organization and functioning of the exhibitions are workshops, storerooms, clubs, outbuildings that allow to recreate in a visual way the life of the population of the Middle Dnieper region of the second half of the 19th - beginning of the 20th centuries.

They are characterized by a narrow specialization (comb-maker's, weaver's, gilmaker`s, potter's, tan ner`s homesteads, homestead of a middle peasant and that of a wealthy peasant and a munufacturer).

A special form of organization and functioning of the exhibitions are workshops, storerooms, clubs, outbuildings that allow to recreate in a visual way the life of the population of the Middle Dnieper region of the second half of the 19th - beginning of the 20th centuries. Among the public buildings of the village there are churches and schools, shops, taverns, andinns. The main exposition is complemented by 13 museums housed in the monument complemented of folk architecture ov in specially built pavillions.

Particularly popular with visitors are the restored archeology monuments unearthed on Pereyaslav Dnieper area and materials of interesting archeological researches from the territory of Ukraine: stone sculptures and funeral boxes of the Kemi-Oba culture; anthropomorphic stelae - the first monumental stone images of people; Polovtsian sanctuaries and burial mounds etc. Attracting tourists to reconstruct the oldest dwelling in the Middle Dnieper, with using the bones of a mammoth (Dobranichivka 
Late Paleolithic) site; an early Slavic dwelling and wooden architecture of the times of Kievan Rus.

In the archeological department of the exposition there are rare wells-logs, metallurgical furnaces, pottery and more. Sacred monuments have a special impact on visitors: the Church of the Intercession of the Blessed Virgin Mary from the village. Of Ostriyky of Bilotserkivskyi district, Kyiv region, 1606, (the interior of the Orthodox church has been reconstructed in the cult building); bell tower from eighteenth century from the village Bushevo Rokytne district of Kyiv region; the hous of the church guard from the beginning of the 19th century; St. George's Church from the village, of Andrushi, Pereiaslav-Khmelnytskyi district, Kyiv region; Cossack churches from the village of Sukhyi Yar of the Stavyshche district and the village of Pyshniki, Skvyra districts of the Kyiv region, stone and wooden crosses from the cemeteries of the Cossack villages of Pereyaslav Region flooded by the waters of the Kaniv Reservoir. The attractive 15 windmills and two watermills, which are located in the museum-village exposition one by one and in groups, satisfy the tastes of modern tourists.

One of the main directions of the activity of the institution is the exposition work, which largely determines the subject of collecting funds and the order of study of museum objects. The main objective of the exhibition is the demonstration of materials that have a solid meaning load. Researchers of the museum conduct quarterly monitoring of the monuments of folk wood architecture, creating plans for the reconstruction and repair of the facilities. The Research Branch of the Museum of Folk Architecture and Life in the Middle Dnieper region, as a tourist mecca of Ukrainian autochthony, arouses people's interest in cultural heritage; helps to understand the value of the spiritual heritage of the people; promotes a better understanding of the historical, socio-economic, cultural, ethnic processes in Ukraine by visitors; shapes the national consciousness of the younger generation. The experience of thescansen builders can be used to create new exhibitions, recreation areas, new museums. It is thanks to the responsible and professional activity of the restorers and scientific staff of the Pereyaslav Scansen that this outstanding center of museum work will have a great impact on the further development of the Ukrainian state and the Ukrainian political nation.

\section{References:}

1. Mikhail Ivanovich Sikorsky: Creator of History and Keeper of Time: a collective monograph dedicated to the 90th anniversary of MI Sikorsky. Pereyaslav National Historical and Ethnographic Reserve, 2013. 